\title{
Characterization of Lectin from Colpomenia Sinuosa and Effect of Physico Chemical Parameters on Haemagglutination Activity
}

\author{
Malini.M.M, Jansi.M, Sini Margret.M, Anooj.E.S, Lekshmi Gangadhar
}

\begin{abstract}
Lectin is a protein which has the ability to bind carbohydrates and named as haemagglutinin. Lectins with specific carbohydrate specificity have been purified from various plant tissues and other organisms and exploited extensively in many aspects of biochemistry and biomedicine. Similar to land plants, lectins from marine algae appear to be useful in some biological applications. Although several studies on lectins from marine algae have been reported till date, few lectins from algae have been characterized in detail. The present study was focused on the lectin isolated from C.sinuosa. The algal lectin has high sugar specificity with $\mathrm{N}$-acetylglucosamine and higher enzyme activity with trypsin. This lectin was identified as $\mathrm{CaCl}_{2}$ dependent - 'C' type lectin and was sensitive to EDTA. Higher H.A titre value was observed with $\mathrm{CaCl}_{2}$ and the lower with $\mathrm{MnCl}_{2}$ and $\mathrm{ZnCl}_{2}$. Significant lectin activity was observed between $\mathrm{pH} 7$ to 8 and temperature between 20 to $40^{\circ} \mathrm{C}$.
\end{abstract}

Keywords: Lectin, algae, haemagglutinin, biochemistry

\section{INTRODUCTION}

"Lectins" has been derived from the Latin word "legere" which has the ability to bind carbohydrates and named as haemagglutinin. Lectins from terrestrial plants and animals have been isolated, characterized and exploited extensively in many aspects of biochemistry and biomedicine. Compared with land plant lectins, the occurrence of lectins from marine algae was first reported by Boyd et al. (1966). The first agglutinin from marine algae was isolated and characterized by Rogers et al. (1977). Similar to land plants, lectins from marine alga reveal a proteinaceous nature but differ in some of their properties. They generally have lower molecular masses than most land plant lectins and are more specific for complex oligosaccharides or glycoproteins. Further, most of marine algal lectins do not require divalent cations for their biological activity. They occur mainly in monomeric form and have a high content of acidic amino acid, with isoelectric points from 4 to 6 (Rogers \& Hori, 1993).

Revised Manuscript Received on October 22, 2019.

Malini M. M*, Research Scholar, (Register Number : 12160, M.S.University, Tirunelveli), Research Department of Zoology, S. T. Hindu College, Nagercoil, Tamil Nadu, India.

Corresponding Email: malinimm23@gmail.com

Jansi M, Associate Professor, Research Department of Zoology, S. T. Hindu College, Nagercoil, Tamil Nadu, India

Sini Margret.M, Assistant Professor, Department of Zoology, Nanjil Catholic College of Arts and Science, Kaliyakkavilai, Kanyakumari District, Tamil Nadu, India.

Anooj E. S, Director, Xcellogen Biotech India Pvt Ltd, Nagercoil, Tamilnadu, India.

Lekshmi Gangadhar, NanoDot Research Pvt Ltd, Nagercoil, Tamilnadu, India.
Although several studies on lectins from marine algae have been reported till date, few lectins from algae have been characterized in detail. Many important biological molecules posess ionisable groups and exist in solution as electrically charged species either as cations or anions at any $\mathrm{pH}$. Under the influence of an electric field these charged particles migrate either to the cathode or to the anode, depending on the nature of their net charge (Janson and Ryden, 1989).

\section{MATERIALS AND METHODS}

Protein purification and characterizations are generally a multi-step process exploiting a wide range of biochemical and biophysical characteristics of the target protein. Each protein offers its own unique set of physicochemical characteristics which are considered to be important in its application. This paper described the biochemical characterization in terms of physico- chemical properties of the agglutinin extracted from $C$. sinuosa was determined.

Description of the algae

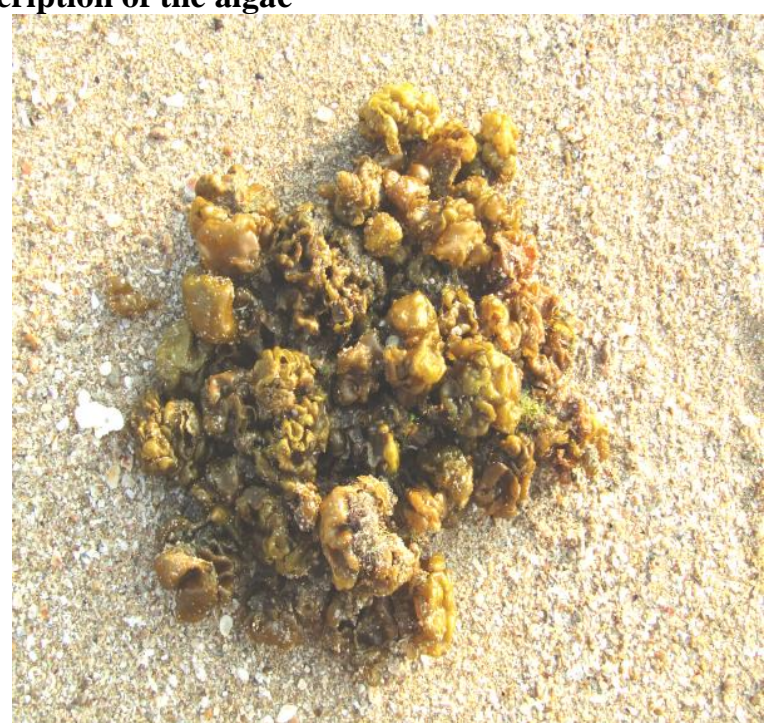

Figure 1. Plate .1 Colpomenia sinuosa (Mertens ex Roth)

Systematics and Description Derbès \& Solier

Empire : Eukaryota

Kingdom : Chromista

Phylum : Ochrophyta

Class : Phaeophyceae

Subclass : Fucophycidae

Order : Ectocarpales

Family 


\section{Characterization of Lectin from Colpomenia Sinuosa and Effect of Physico Chemical Parameters on Haemagglutination Activity}

Scytosiphonaceae

Genus : Colpomenia

Species : sinuosa

Plants smooth, hemispherical, irregularly lobed, golden brown hollow - $30 \mathrm{~cm}$ diameter and $10 \mathrm{~cm}$ high, with multiple attachments to substrate. Often covered with fine colourless hairs. Reproductive sori as dark raised patches on surface. Thallus membranaceous, $300-500 \mathrm{~cm}$ thick, 4-6 cell layers. Plurilocular sporangia cylindrical to club-shaped, $3.7-8 \mathrm{~cm}$ diameter, $18-30 \mathrm{~cm}$ long, in dense clusters, scattered on surface. Lower intertidal to $15 \mathrm{~m}$ deep. Firmly attached to hard surfaces or epiphytic on other organisms (Plate.1).

\section{Enzyme induced haemagglutination assay} assay were tested with enzymes such as trypsin, neuraminidase and papain following the method described by Maheswari et al. (1997), saline washed rabbit and human erythrocytes were resuspended in the TBS containing 5mg/ $\mathrm{ml}^{-1}$ trypsin, neuraminidase and papain separately and incubated for 1 hour at $37^{\circ} \mathrm{C}$ with occasional shaking. The enzyme treated red blood cells were washed with $0.9 \%$ saline by centrifuging at $4000 \mathrm{rpm}$ for 5 minutes at room temperature. Finally the RBC's were fixed by suspending it in TBS ( $\mathrm{pH} 7.6$ ) containing $10 \%$ formaldehyde for 24 hours at $10^{\circ} \mathrm{C}$. Enzyme fixed red blood cells were extensively washed in $0.9 \%$ saline or TBS. Enzyme induced haemagglutination assay was performed with lectin sample separately for different enzymes treated RBC's and the activity was recorded.

\section{Sugar specificity of C. sinuosa lectin (Inhibition Assay)}

The lectin's sugar specificity was carried out following the standard procedure of Faria et al. (2004) by comparing the inhibitory activity of various sugar solutions such as, $\mathrm{N}$-acetyl glucosamine, N-acetyl neuraminic acid, glucosamine, mannose, lactose, fucose, sucrose, fructose, rhamnose, ribose, maltose, trehalose, dextrose, sorbitol and galactose, on hemagglutination of human $\mathrm{O}^{+}$erythrocytes. 25 $\mu \mathrm{l}$ of lectin dilution was placed on microtitre ' $\mathrm{V}$ ' plates and incubated for $1 \mathrm{hr}$ at $37^{\circ} \mathrm{C}$ with $25 \mu \mathrm{l}$ of sugars at different concentration. Subsequently, $25 \mu \mathrm{l}$ of a $2 \%$ human $\mathrm{O}^{+}$ erythrocytes suspension in TBS was added. The specificity was also determined using glycoproteins such as mucin and fetuin. The inhibitory capacity was expressed as the minimum concentration of the carbohydrates and glycoproteins which are required to inhibit haemagglutination activity. Inhibition assays were performed in triplicate. The results were expressed as the minimum concentration of the inhibitor required to terminate the agglutination completely.

\section{Cation dependency and EDTA sensitivity}

According to the method of Pandolfino and Magnuso (1980) the cation dependency and EDTA sensitivity of haemagglutination activity of C.sinuosa lectin was determined in TBS containing different concentration of

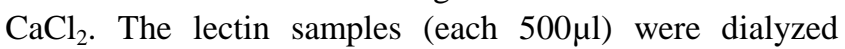
extensively against TBS (to test divalent cation dependency) or in TBS-EDTA (to examine EDTA sensitivity) at $15^{\circ} \mathrm{C}$. The samples were dialyzed against TBS-EDTA and were
Enzymes that induce and increase the haemagglutination

subsequently re-equilibrated by dialysis in TBS. After centrifugation (4000 rpm for 5 minutes at room temperature) the supernatant was used to determine the haema glutinating activity with human $\mathrm{O}^{+}$erythrocytes.

\section{Effect of metal cation on haemagglutination activity of $C$. sinuosa lectin}

The effect of divalent metal ions on lectin activity was assessed by extensive dialysis of C.sinuosa lectin sample against TBS containing different concentration of metal ions such as $\mathrm{CaCl}_{2}, \mathrm{MgCl}_{2}, \mathrm{ZnCl}_{2}, \mathrm{MnCl}_{2}, \mathrm{FeCl}_{2}$ and $\mathrm{MnSO}_{4}(\mathrm{pH}$ 7.6) for $24 \mathrm{~h}$ at $5^{\circ} \mathrm{C}$ as described by the method of Pandolfino and Magnuso (1980). The haemagglutination activity was determined with RBC suspended in TBS before and after addition of metal ions.

Table 1: Enzyme induced haemagglutination activity

\begin{tabular}{|l|c|c|c|c|}
\hline \multirow{2}{*}{} & \multicolumn{4}{|c|}{ Blood group } \\
\cline { 2 - 5 } & $\mathbf{A}^{+}$ & $\mathbf{B}^{+}$ & $\mathbf{O}^{+}$ & $\mathbf{R}$ \\
\hline Trypsin & 256 & 128 & 1024 & 256 \\
\hline Papain & 32 & 16 & 512 & 64 \\
\hline Neuraminidase & 2 & - & - & - \\
\hline
\end{tabular}

Effect of $\mathrm{pH}$ and thermal stability

The C.sinuosa sample $(500 \mu \mathrm{l})$ was dialyzed against the buffers such as acetate buffer, Tris- $\mathrm{HCl}$ and glycine $\mathrm{NaOH}$ at the $\mathrm{pH}$ ranging from 3.5 to 10 . After dialysis, all the samples were again finally equilibrated by dialysis against TBS. The dialysates were centrifuged and the supernatant was tested for haemagglutinating activity using human $\mathrm{O}^{+}$erythrocytes. Thermal stability of sample was examined by holding $100 \mu 1$ of samples for $30 \mathrm{~min}$ at temperature ranging from $10-80^{\circ} \mathrm{C}$. All the samples were centrifuged and the clear supernatant was used to determine agglutination activity with human $\mathrm{O}^{+}$ erythrocytes.

\section{RESULTS}

Enzyme induced haemagglutination assay

Erythrocytes treated with enzymes were tested for HA activity and the results revealed that trypsin treated $\mathrm{O}^{+}$ erythrocytes showed increased activity when compared with $\mathrm{A}^{+}, \mathrm{B}^{+}$and rabbit $(\mathrm{R})$ erythrocytes. The highest $\mathrm{HA}$ titer value was observed with trypsinized $\mathrm{O}^{+}(1024)$ followed by trypsinized rabbit $\mathrm{A}^{+}$erythrocytes (256). Trypsinized $\mathrm{B}^{+}$ erythrocytes exhibited a HA titre of 128 (Table.1). Among the papain treated human erythrocytes, $\mathrm{O}^{+}$showed the highest titre value of 512 similar to that of trypsin treated human $\mathrm{O}^{+}$erythrocytes and the other erythrocytes showed a reduced titre ratio of 32 for $\mathrm{A}^{+}$and 16 for $\mathrm{B}^{+}$and 64 for rabbit (R) erythrocytes. But the neuraminidase treated human $\mathrm{A}^{+}$ erythrocytes only showed the lowest titre ratio of 2 and the other neuraminidase treated erythrocytes did not show HA activity. 
Sugar specificity of C.sinuosa (Inhibition Assay)

The sugar specificity of C.sinuosa lectin was assessed by haemagglutination inhibition efficiency by various sugar and glycoproteins. The result revealed that $\mathrm{N}$-acetyl glucosamine produced higher inhibitory activity (32) among the used sugars, followed by $\mathrm{N}$-acetyl neuraminic acid (16) and mannose (8). The other sugars such as lactose, sucrose,

Table 2: Tested results

\begin{tabular}{|c|c|c|}
\hline $\begin{array}{c}\text { Sugar and } \\
\text { glycoproteins } \\
\text { tested }\end{array}$ & $\begin{array}{c}\text { Max.Concentratio } \\
\text { n tested(mM) }\end{array}$ & $\begin{array}{c}\text { H.A.Inhibition } \\
\text { titre }\end{array}$ \\
\hline $\begin{array}{c}\text { N-acetyl } \\
\text { glucosamine }\end{array}$ & 200 & 32 \\
\hline $\begin{array}{c}\text { N-acetyl } \\
\text { neuramic acid }\end{array}$ & 200 & 16 \\
\hline Glucosamine & 200 & - \\
\hline Mannose & 200 & - \\
\hline Lactose & 200 & - \\
\hline Fucose & 200 & - \\
\hline Sucrose & 200 & - \\
\hline Fructose & 200 & - \\
\hline Rhamnose & 200 & - \\
\hline Ribose & 200 & - \\
\hline Maltose & 200 & - \\
\hline Trehalose & 200 & - \\
\hline Dextrose & 200 & - \\
\hline Sorbitol & 200 & - \\
\hline Galactose & 200 & - \\
\hline Fetuin & 100 & - \\
\hline Mucin & 200 & - \\
\hline
\end{tabular}

fructose, ribose, maltose, trehelose, dextrose, sorbitol, galactose, rhamnose, did not show any inhibitory activity against C.sinuosa lectin (Table.2).

In the case of glycoproteins, fetuin and mucin were the potent inhibitors of agglutinin and had scored inhibitory efficiency with the HA titre of 8 . The result revealed that the sample isolated from the alga C.sinuosa contain a lectin which has high specificity for $\mathrm{N}$-acetyl glucosamine.

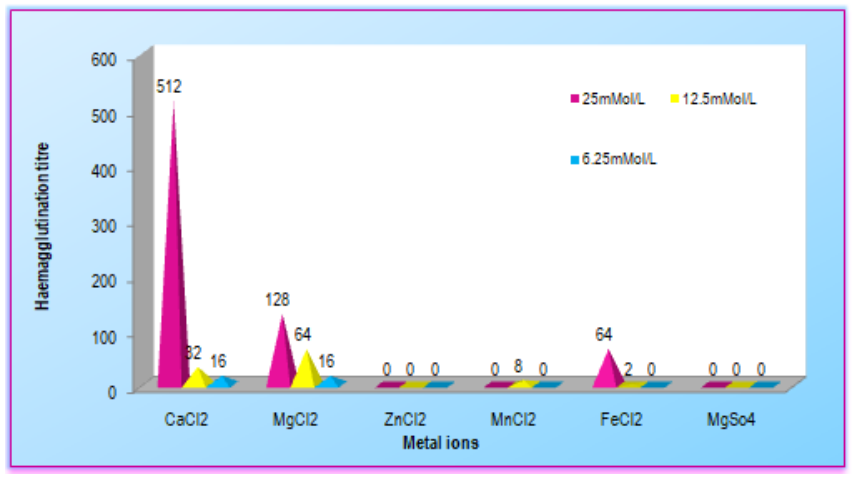

Fig.2 Effect of metal ions on haemagglutination activity

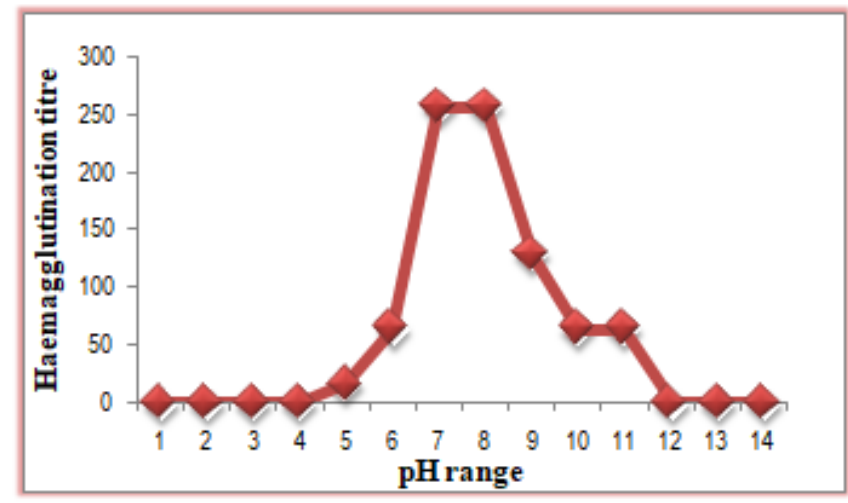

Fig.3 Effect of pH on haemagglutination activity of

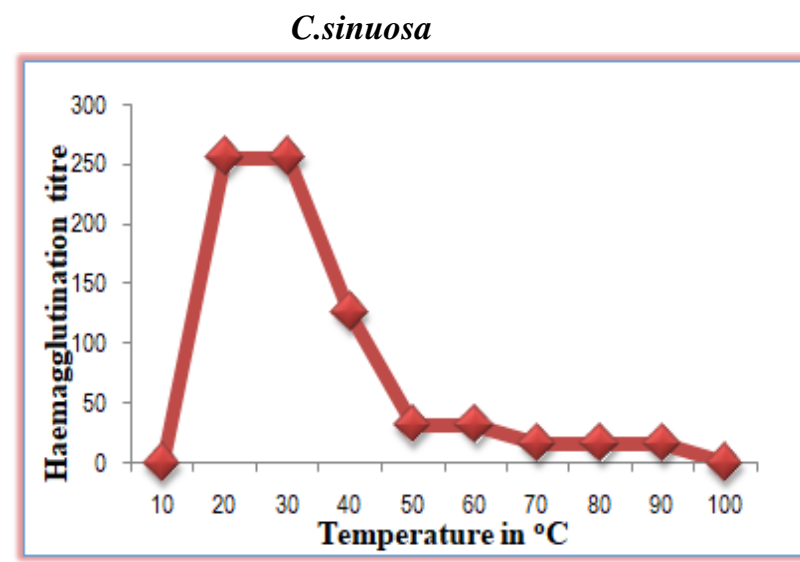

Fig.4 Effect of temperature on haemagglutination activity of C.sinuosa lectin

Cation dependency and EDTA sensitivity

C.sinuosa lectin was confirmed to be $\mathrm{Ca}^{2+}$ dependent lectin. The lectin was tested with various concentrations $(6.25,12.5,25,50,100 \mathrm{mM})$ of calcium ions dialyzed in TBS or in TBS- EDTA at different concentrations. The lectin agglutinated various animal erythrocytes depending on the presence of calcium ions and the activity was abolished in the absence of $\mathrm{CaCl}_{2}$ as well as in the presence of EDTA. The highest $\mathrm{HA}$ activity (512) of lectin was observed with $\mathrm{CaCl}_{2}$ concentration of $25 \mathrm{mM}$. The increase or decrease in calcium ion concentration lead to a decrease in HA activity of lectin. Thus the lectin was identified as calcium dependent or ' $\mathrm{C}$ ' type lectin and was insensitive to EDTA.

Effect of metal cations on haemagglutinating activity of C.sinuosa Lectin

The lectin was tested with different concentration of divalent cations such as $\mathrm{CaCl}_{2}, \mathrm{MgCl}_{2}, \mathrm{ZnCl}_{2}, \mathrm{MnCl}_{2}, \mathrm{FeCl}_{2}$ and $\mathrm{MgSO}_{4}$ for the determination of HA activity. Among the experimental data, $25 \mathrm{mM}$ concentration of $\mathrm{CaCl}_{2}, \mathrm{MgCl}_{2}$ and $\mathrm{FeCl}_{2}$ showed higher $\mathrm{HA}$ activity. The haemagglutination titre value increased up to 512 for $\mathrm{CaCl}_{2}$, 128 for $\mathrm{MgCl}_{2}$ and 64 for $\mathrm{FeCl}_{2}$ at the concentration of $25 \mathrm{mM}$ and a decrease in concentration expressed lower activity. 


\section{Characterization of Lectin from Colpomenia Sinuosa and Effect of Physico Chemical Parameters on Haemagglutination Activity}

Table :2 Sugar specificity of algal lectin (C.sinousa)

The other cations like $\mathrm{MnCl}_{2}$ and $\mathrm{ZnCl}_{2}$ showed very low haemagglutination titre value, but $\mathrm{MgSO}_{4}$ did not produce any significant HA activity on lectin (Fig.1).

\section{Effect of pH on haemagglutination Activity}

Significant lectin activity was observed between $\mathrm{pH} 7.0$ and 8.0 and the activity slowly reduced below $\mathrm{pH} 7.0$ and above $\mathrm{pH}$ 8. At $\mathrm{pH} 5$ and $\mathrm{pH} 12$ the haemagglutination activity was completely abolished. Thus the agglutinating property of lectin to agglutinate human $\mathrm{O}^{+}$erythrocyte was stable between $\mathrm{pH} 7.0$ and 8.0 (Fig.2).

Effect of temperature on haemagglutination activity of C.sinuosa lectin

The temperature range of haemagglutination activity of lectin to agglutinate human $\mathrm{O}^{+}$erythrocyte was stable between $20^{\circ} \mathrm{C}$ and $40^{\circ} \mathrm{C}$. The activity titer was reduced above $40^{\circ} \mathrm{C}$ which leads to the loss of activity at $100^{\circ} \mathrm{C}$ and below $20^{\circ} \mathrm{C}$. Hence the protein was suggested to be a heat sensitive protein (Fig.3).

\section{DISCUSSION}

Algal lectins are in general more specific for complex oligosaccharides often glycoproteins (Rogers and Hori, 1993). Haemagglutination is referred to the presence of proteins or glycoproteins having specificity for carbohydrate binding selectively to red blood cells. These proteins are found in sap of some marine algae (Boyd et al., 1966). The haemagglutination assay of crude extract of C.sinuosa showed a higher titre value of 512 with human $\mathrm{O}^{+}$ erythrocytes which also agglutinated other blood types such as $\mathrm{A}, \mathrm{B}, \mathrm{A}^{-}, \mathrm{B}^{-}, \mathrm{O}^{-} \mathrm{A1}^{+}$and $\mathrm{AB}^{+}$with low titre value. Haemagglutination assay of C.sinuosa with animal blood erythrocytes revealed a higher titre value of 128 with rabbit erythrocytes $(\mathrm{R})$, whereas goat $(\mathrm{G})$ and hen $(\mathrm{H})$ erythrocytes showed very low activity. Enzyme induced haemagglutination assay of C.sinuosa lectin with trypsin, papain and neuraminidase revealed that the trypsin treated human $\mathrm{O}^{+}$erythrocytes exhibited increased HA activity of 1024. Papain treated human $\mathrm{O}^{+}$erythrocytes alone showed the higher activity of 512 and the other erythrocytes showed relatively less activity. Neuraminidase treated $\mathrm{O}^{+}$ erythrocytes did not show any significant haemagglutination activity with C.sinuosa lectin. Trypsinization of erythrocytes increased the haemagglutination activity which may be due to the exposure of the cryptic receptor sites on the cell membrane and the removal of close interfering structure after protease digestion on the erythrocytes (Marilyn Holm et al., 1987). Similar to our report, Gottschalk and Drzeniek (1972) also observed that neuraminidase treated rabbit and human erythrocytes showed lower activity. The agglutination activity of C.sinuosa lectin with erythrocytes of most human blood group revealed that the specificity of lectin to several sugars and glycoproteins. Sugar specificity of C.sinuosa lectin revealed that it has high specificity for $\mathrm{N}$-acetyl glucosamine produced higher inhibitory activity (32) with C.sinuosa lectin. As in our report, $\mathrm{N}$-acetyl glucosamine was reported to inhibit agglutination activity in Codium giraffe (Alvarez - Hernandez et al., 1999) and Didemnum ternatanum (Odintsova et al., 2001).

Metal ion dependency of haemagglutination activity of C.sinuosa lectin was tested using various metal ions such as $\mathrm{CaCl}_{2}, \mathrm{MgCl}_{2}, \mathrm{ZnCl}_{2}, \mathrm{MnCl}_{2}, \mathrm{FeCl}_{3}$, and $\mathrm{MgSO}_{4}$. Among the experimental data, $25 \mathrm{mM}$ concentration of $\mathrm{CaCl}_{2}$ exhibited the highest HA activity with lectin and lower activity was observed with a decrease in concentration of $\mathrm{CaCl}_{2}$. Marine lectins are generally identified by their metal ion requirement for their haemagglutination activity. C-type lectins are specific to carbohydrate recognition proteins which play crucial roles in the innate immunity. C.sinuosa lectin was considered to be calcium dependent as its activity was restored by the addition of $\mathrm{CaCl}_{2}$. Similar to our report Renuka Bai (2001) and Randy Chi Fai Cheung (2015) also observed that the agglutination activity of lectin in P.pastoris also required $\mathrm{Ca}^{2+}$ ions. The lectins from red algae Ptilota serrata (Rogers et al., 1990), Ptilota filicina (Sampaio 1998 b), Enantiocladio duperreyi (Benevides et al., 1998) and from green algae Ulva lactuca (Sampaio et al., 1998) exhibited dependence of metals such as $\mathrm{Ca}_{2}{ }^{+}$and Mn2. Few lectins do not require any metal ions for their activity (Yang et al., 2007). Lectin from marine red alga, Gracilaria cornea is an acidic, monomeric glycoprotein that does not require divalent metal ions for its haemagglutinating activity. The lectin from the venom of the Hawaiian box jellyfish (Carybdea alata) showed similar result in which the HA activity was irreversibly lost after dialysis of crude venom against divalent-free, $20 \mathrm{mM}$ EDTA buffer which was optimal in the presence of $10 \mathrm{mM} \mathrm{Ca}^{2+}$ or $\mathrm{Mg}^{2+}$ (John Chung et al., 2001). Similar result was documented from lectin of starfish, A. pectinifera where the haemagglutination activity of lectin was completely abolished by chelating agent such as EDTA or EGTA and the activity was completely restored by the addition of $\mathrm{CaCl}_{2}$ (Mari Kakiuchi et al., 2002). Thermal stability of C.sinuosa lectin with respect to its haemagglutination activity was stable at temperature range between $20^{\circ} \mathrm{C}$ to $40^{\circ} \mathrm{C}$ and the activity titre value has a sharp decrease above $40^{\circ} \mathrm{C}$ and finally the activity was completely lost at $80^{\circ} \mathrm{C}$ and below $20^{\circ} \mathrm{C}$.

\section{CONCLUSION}

The thermostability of proteins depend on its increased content of charged amino acid residues and revealed that the haemagglutination capacity of the lectin was not affected by exposure to a temperature of $30-70^{\circ} \mathrm{C}$ for 30 minutes. The effect of $\mathrm{pH}$ on C.sinuosa lectin to agglutinate human $\mathrm{O}^{+}$ erythrocyte indicated that the lectin was stable at $\mathrm{pH}$ range between 7.0 and 8.0 and the activity gradually reduced below $\mathrm{pH} 7.0$ and above $\mathrm{pH}$ 8.0. At $\mathrm{pH} 5$ and $\mathrm{pH} 10.0$ the haemagglutination activity was completely abolished. At $\mathrm{pH}$ 8 the HA activity was greatly reduced at more than $50 \%$ of the original activity scored. But the effect of $\mathrm{pH}$ on C.sertularioides was found to be active over the range of 5.0 to 10.5 . The effect of $\mathrm{pH}$ on the lectin revealed that the haemagglutination activity of U.pertusa lectin was unaltered at $\mathrm{pH}$ 6-8. 
The algal lectin has high sugar specificity with $\mathrm{N}$-acetylglucosamine and higher enzyme activity with trypsin. This lectin was identified as $\mathrm{CaCl}_{2}$ dependent - ' $\mathrm{C}$ ' type lectin and was sensitive to EDTA. Higher H.A titre value was observed with $\mathrm{CaCl}_{2}$ and the lower with $\mathrm{MnCl}_{2}$ and $\mathrm{ZnCl}_{2}$. Significant lectin activity was observed between $\mathrm{pH} 7$ to 8 and temperature between 20 to $40{ }^{\circ} \mathrm{C}$.

\section{REFERENCES}

1. Alvarez-Hernandez S, Lara-Isassi GD, Arreguın-Espinoza R, Arreguin B, Hernandez-Santoyo A, Rodriguez-Romero A (1999). Isolation and partial characterization of giraffine, a lectin from the Mexican endemic alga Codium giraffa Silva. Bot Mar 42:573-580.

2. Benevides, N.M.B., Holanda, M.L., Melo, F.R., Freitas, A.L.P. \& Sampaio, A.H. 1998. Purification and partial characterisation of the lectin from the marine red alga Enantiocladia duperreyi (C. Agardh) Falkenberg. Botanica Marina 41:521-525.

3. Boyd W C, Almodovar L R and Boyd L G (1966). Agglutinins from marine algae for human erythrocytes; Transfus. 6: 82-83.

4. Faria, R.A., Andrade Neto, M., Pinto, L.S., Castellon, R. R., Calvette, J.J. and Cavada, B.S. (2004). Archivos Latinoamericanos de Nutricion, Vol.54: 349-353.

5. Gottschalk, A. and Drzeniek, R. (1972). Neuraminidase as a tool in structural analysis. In Glycoproteins, Their Composition, Structure and Function, 2nd edn Edited by A. Gottschalk. Amsterdam: Elsevier Publishing Co.pp: 381-402.

6. Janson, J.C. and Rydén, L (1989). Protein Purification. Principles, High Resolution Methods and Applications. VCH Publishers, New York.

7. John J. Chung, Lal A. Ratnapala, Ian M. Cooke and Angel A. Yanagihara (2001). Partial purification and characterization of a hemolysin (CAH1) from Hawaiian box jellyfish (Carybdea alata) venom. Toxicon. Volume 39: 981-990.

8. Mari kakiuchi, Nozomo okino and Makoto Ito., (2002). Purification, identification and C- DNA cloning of $\alpha-\mathrm{N}$-acetylgalactosamine-specific lectin from starfish Asterina pectinifera.

9. Marilyn, S., Holm., ANn. E. Berger., KENNETH SwANSON AND LEONARD. C. GINSBERG. (1987). EFFECT OF TRYPSINIZATION ON LECTIN BINDING TO GERM CELLS FROM ICR AND T/T6. BIOLOGY OF REPRODUCTION, 37: 282-287

10. Lekshmi Gangadhar and P. K Praseetha, A Green Approach to Sustainable Energy using Quantum Dots, International Journal of Recent Technology and Engineering, ISSN: 2277-3878, Vol. 8, 345-350, 2019.

11. Lekshmi Gangadhar and P. K Praseetha, Identification and Molecular Phylogenetic Relationship of Selected Medicinal Plants-Ethano Medicinal Importance, Indian Journal of Public Health Research \& Development, ISSN: 0976-0245, Vol. 10,14-18, 2019.

12. Odintsova, N.A., Belogortseva, N.I., Khomenko, A.V., Chikalovets, I.V. and Luk'yanov, P.A. (2001). Effect of lectin from the ascidian on the growth and the adhesion of HeLa cells. Mol. Cell. Biochem, 221: 133-138.

13. Pandolfino E.R. and Magnuso J.A. (1980). $\mathrm{Mn}_{2}{ }^{+}$and $\mathrm{Ca}_{2}{ }^{+}$binding to the Lima bean lectins. J Biol Chem, 255:870-873.

14. Randy Chi Fai Cheung, Tzi Bun Ng, Jack Ho Wong and Wai Yee Chan(2015). Chitoson: An update on potential Biomedical and Pharmaceutical applications. Mar.Drugs,13, 5156-5186.

15. Renuga Bai.N (2001). N-acetyl neuramic acid recognizing lectin from the extract of marine alga, Sargassum cristaefolium, C.Ag. M.S.University, Tirunelveli,India.

16. Rogers DJ (1977). Antibody-like substances in marine organisms. In Faulkner DJR, Fenical WH (eds), Marine Natural Products Chemistry, 310-327.

17. Rogers D.J, Fish B and Barwell CJ (1990). Isolation and properties of lectins from two red marine algae: Plumaria elegans and Ptilota serrata; in Lectins: biology, biochemistry, clinical biochemistry (eds) TC Bog-Hansen and DL JFreed (St Louis: Sigma Chemical Company) pp 49-52.

18. Rogers, D. J and Hori, K. (1993). Marine algal lectins: new development. Hydrobiol. 260/261: 589-593.

19. Sampaio, A. H., Rogers, D. J., Barwell, C. J. (1998). Isolation and characterization of the lectin from the green marine alga Ulva lactuca L. Bot Mar. 41, 427-433.
20. Shen Wang, Fu Dizhong, Yong-Jiang Zhang, Zu-Jian WU, Qi-Ying LIN and Lian-Hui XIE(2004). Molecular characterization of new lectin from the marine alga Ulva pertusa. Acta Biochimica et Biophysica Sinica,36(2):111-117.

21. Sudhir Kumar(2011). Isolation and studies of marine algae lectins Goa University, Goa, India. 